Tequio 3(9), 2020: 9-22

ISSN: 2594-0546

\title{
STEM access for Latina bilingual teacher candidates: Discrimination en la educación How do informal programs motivate women to pursue STEM related fields
}

\author{
Margarita Machado-Casas, ${ }^{1}$ Katherine Talati $\&$ Ana Baron ${ }^{3}$
}

Fecha de recepción: 13 de septiembre de 2019

Fecha de aceptación: 14 de noviembre de 2019

\begin{abstract}
The lack of proper representation of women of color in the field of bilingual science, technology, engineering, and math (STEM) is a crucial matter when addressing the needs of the US as a country moving toward diversity and inclusion. The research project represented in this paper investigates and addresses the need for teacher preparation courses that will adequately set up their bilingual preservice teachers to enter into the field with the proper background experiences to engage their future students in STEM related lessons. Findings reveal the negative ideologies related to gender bias found in teacher education, the importance of STEM related women empowerment, and how those vested in STEM education must continue to debunk the impostor syndrome felt by students in STEM related fields. Despite the challenges present for women in bilingual teacher preparation programs in STEM, we must continue to create sanctuaries where students of color can thrive in environments that are conducive to their unique experiences and fulfill their learning needs in STEM.
\end{abstract}

\section{Keywords:}

STEM, women, education, teacher education.

${ }^{1}$ San Diego State University. ORCID: 0000-0003-2051-2444

2 Texas A\&M University San Antonio. ORCID: 0000-0001-6939-350

${ }^{3}$ San Diego State University. ORCID: 0000-0002-0613-2755 


\section{Introduction}

he condition of Latina/o students in the United States has received considerable attention over the last several years (Gandara \& Contreras, 2009). As noted by Mercado, "insufficient attention has been paid in developing teacher capacities for teaching students from marginalized communities" (Mercado, 2012, p. 24). This is especially the case of women of color going into the bilingual science technology, engineering and math (STEM) field. STEM and bilingual education have been noted as areas of high need by the US Department of Education and areas in which there is a sizeable shortage of teachers. And Grant points out that "concerns over low achievement levels in mathematics and science have propelled educators in these fields to take the lead in determining teacher capacities, but these assessments typically use traditional 'neutral' framework in which the role of race or power is left unexamined" (Grant, 2008, p. 24). Much has improved in terms of graduation rates of Latinos in the US. However, disparities in high school graduation rates between Latinas/os and White students are still challenging (Rodríguez, 2014; Swanson, 2004). There are many factors that influence the dropout rate among Latina/os in the US -the lack of opportunities is one of them, but there are other differences based on race, class, gender, and immigration status, plus the current anti-Latino sentiment affecting the US today (Orfield, 2004; Orfield, Losen, Wald \& Swanson, 2004; Rodríguez, 2014; Miron, 1996). These historical and policy-driven conditions contribute to perpetuate an undereducated polity with detrimental effects for the United States, especially among Latinas/os who not only are the largest and fastest growing minority group in the country, but also constitute a majority of all school-aged children in states such as California and Texas (Fry \& Lopez, 2012; Gandara \& Contreras, 2009). As noted by Ladson-Bilings (2005), diversity in the teaching field means portraying an accurate picture of today's current multicultural and democratic society -one that includes gender. Despite the demographic significance of Latinos in the United States and its public schools specifically, who constitute nearly one fourth of all K-12 students nationally, it is clear that any undereducated group of people is not only far less likely to compete globally and promote economic growth for local communities, but is also less likely to participate in conventional politics (i.e., voting), less likely to have access to fair wages, health care, and thriving communities (Anyon, 1997; 2005).

\section{Informal learning experiences: Promoting STEM in higher education for women educators}

Informal learning can take place in any space outside a school, a that does not follow a regular school curriculum. Since, in most cases, learning takes place beyond school hours, several researchers have explored the benefits of activities that have been implemented as a part of extended, informal learning or after-school programs. Such programs regularly ran as part of other after-school activities, and often take a different approach when they are implemented in a university teacher preparation program, as they have to follow a strict university schedule (MachadoCasas \& Alanís, 2015). Such investigations have shed light on situated learning processes (Lave \& Wenger, 1991). For example, La Clase Mágica (LCM), an afterschool bilingual and bicultural technology program, has demonstrated the utility of learning as it occurs in a setting in which the learner is at the center, learning is guided through the zone of proximal development, horizontal dialogue occurs, and in which social imagination abounds (Vasquez, 2003; Flores, Vasquez \& Clark, 2014). The benefits of informal learning activities are evident as learners continue to engage in problem-solving and critical thinking (Lecusay, 2015; Schuetze, Claeys, Flores \& Sczech, 2014). As a form of expansive learning (Engestrom, 2001) within a community of practice (Lave \& Wenger, 1991), Schuetze Claeys, Flores and Sczech (2014) used several studies that have identified how 
critical it is to incorporate these specialized fields within the university level, especially as it pertains to STEM fields. The more exposure to these subjects university students get, the more likely they will be to connect with them. Therefore, the settings inside or outside university classrooms are critical in allowing students possibilities, especially those that refer to field-based professions, such as the teaching field. Informal learning opportunities play a key role, especially as a way for students to connect to a field of study. Schuetze Claeys, Flores and Sczech observed that the expansive learning activities mutually fostered "creativity, imagination, recursive discovery process, and natural curiosity" (2014, p. 39). These are the types of activities needed within the teaching profession in order for teaching candidates to accumulate experience and be encouraged to choose a STEM related field with a bilingual education emphasis. These highly specialized fields are often ignored or simply not addressed in relation to STEM. Another study finding was the transferability of the concepts learned. In other words, what was learned in the robotics clubs was then applied to the daily classroom lessons. This concept can be used in relation to scientific language in Spanish -its transferability has to be made visible in order for future teachers to see the connection and the necessity.

\section{Theoretical framework}

In today's time restrictive world, informal activities can provide a way to expose students to various methods and fields of study (Machado-Casas \& Alanís, 2015; Machado-Casas, Alanís \& Ruiz, 2017). This becomes particularly important when working in areas of high need, such as STEM and bilingual education. According to Flores, Vasquez and Clark (2014), La Clase Mágica (LCM) informal activities generate a transworld pedagogy which honors and is anchored in Vygotsky's notion of culture, dialogic discourse, the sacred sciences, and critical pedagogy. Incorporating Vygotsky's notion of culture in informal activities suggests that we see the individual as a culturalhistorical being with multiple knowledges, which are used in anchoring new learning and development. As noted by Diaz and Flores (2001), scientific concepts can only be transformed from everyday concepts within a school setting. They note that these are important for higher order thinking abilities and for the continued intellectual and personal development of an individual. Hence, prior cultural knowledge is cultivated in a manner in which active and expansive learning occurs. Additionally, "the use of [egalitarian] communicative strategies in educational contexts to facilitate social inclusion of underrepresented groups is clearly one of the most important implications of LCM" (Avidad, 2014. p. 35). In this study, we use the egalitarian framework to meaning-making as it refers to the experiences of women in bilingual STEM. Drawing from the understanding that all people are equal and deserve equal rights and opportunities, we focus on the sacred knowledge that many future bilingual STEM students do not get when in a credential program.

Thus, the Nepohualtzintzin uses the notion of sacred sciences from an indigenous philosophy in which all creation is considered sacred and, as such, requires that we maintain a harmonious balance with the cosmos. According to Prieto, Claeys and Lara, the "Nepohualtzitzin is an important contemporary mathematical tool. The design and development of Nepohualtzitzin Ethnomathematics Clubs (NECs) in predominantly Latina/o and low-income schools is also presented.NECsprovideinformallearningopportunities to develop and strengthen cultural connections to and abilities in mathematics for bicultural bilingual learners, their parents, and teacher candidates" (Prieto, Claeys and Lara, 2015, p. 125). Indigenous scientific thought was born out of observation and exploration of the cosmos. The Nahuas used mathematics to explain the connection among humankind, nature, and the cosmos. Specifically, in the case of the Nepo, while a tool for numerical computation, it symbolizes the 
Nahua cosmovision with its use of sacred numbers synchronizing humankind, nature, and the cosmos (Prieto, Claeys and Lara, 2015). For example, a base of 20 is used because as human beings we have twenty digits (fingers and toes); it uses the sacred number 13 because it reflects the phases of the moon as well as the major joints in the human body. The Nepo is held in a vertical manner to acknowledge transcendence of thought and mind towards the cosmos (Prieto, Claeys and Lara, 2015). Exposing future bilingual teachers to the Mesoamerican pedagogies and allowing them to connect with STEM practices, but also their culture, poses a new approach of looking at and working with STEM.

\section{Data collection and analysis}

For this study we used qualitative survey (Knobel \& Lankshear, 1999) to examine our case study of one bilingual teacher candidate (BTC) cohort in an informal educational setting -a weekend training session. Qualitative survey designs maximize data collection within a minimum amount of time and thus allows qualitative data to be efficiently gathered and analyzed (Marsland, Wilson, Abeyasekera \& Kleth, 1999). Using field-based observations, in-class discussions, and artifact collection, a team of researchers gathered data from the STEM related activities students engaged in during this time. Out of those encounters a series of questions was shared with students that shed light on the ways women of color, in this case mostly Latinas, felt about the exposure to STEM and the ways they were discriminated against -willingly or unwillingly via institutional practices they experienced.

\section{Setting}

As part of a bilingual teacher preparation program in CA, teachers took part in a STEM related seminar, a follow up questionnaire, and activities that analyzed their views on STEM, but also shed light on the ways in which schools have not promoted STEM related activities. 35 teacher candidates took part in a training on the Nepohualzitzin Ethnomathematics Club (NEC), which is one of three Academy for Teacher Excellence research-based after-school programs under the umbrella of La Clase Mágica (LCM) (Prieto, Claeys and Lara, 2015). LCM@UTSA, modeled after Vasquez' (2003) California community-based LCM after-school programs, promotes bilingualism and cultural revitalization through the integration of technology among young learners, teacher candidates, undergraduate student-mentors and club sponsorsteachers. These clubs "provide bilingual and culturally diverse learners (protégés) with playful informal learning opportunities that promote creativity, mathematical, and scientific skills along with other forms of literacy" (Schuetze, Claeys, Flores \& Sczech, 2015, p. 28).

Bilingual teacher candidates took part in a twoday training around the use of the Nepohualzitzin Ethnomathematics Club. The training included a sociohistorical approach to the role of Mesoamerican in STEM and how it involves cultural facts and hands-on activities related to culture and STEM but were also followed by digital discussions and post surveys. During this two-day training bilingual teacher candidates shared their experiences in relation to the STEM field and addressed the need for schools to provide these types of activities at the university level.

\section{Participants}

Because the study sought to focus on the relationship between STEM and pedagogy, and STEM believes that is how pedagogy is translated into action and expectations, we studied 35 participants that took part on the Nepohualzitzin Ethnomathematics Club training as part of an informal training opportunity while in their bilingual teacher education program. Participants were overwhelmingly female, firstgeneration college students, ranging in ages from their early 20's to 50's. All of them were in the second semester of their teacher preparation program. Many were of Mexican origin with varying levels of Spanish/ 
English bilingualism and STEM experience. Out of the 35 students, about half addressed STEM and five agreed on completing more in-depth questions.

\section{Data collection}

Because the goal was to document BTCs growth in their development as future teachers, data was collected in several different ways and at different times. Data collection occurred during training with follow up dialogue during the semester.

\section{Pre and post surveys}

BTCs were administered a pre and post survey that explored their ideas and thoughts about math, culture, and the use of a "manipulative" type tool to teach in formal and informal settings. According to the Hanover Research Institute (2013), "research on the use of student perception surveys in $\mathrm{K}-12$ education has not been extensive; however, studies consistently suggest that student surveys are a reliable measure of teacher effectiveness" (2013, p. 3). Surveys were not graded and therefore were not a factor in the determination of final grades. However, the students in all sections were told that they had to take both surveys and answer the questions in a conscientious manner to complete the training or any of the courses for their teacher credential program.

\section{Sacred STEM reflections}

BTCs documented their experiences in the Nepo training right after they got it. And later engaged in what we called "sacred STEM reflections", as they were more personal reflections of their past and present experiences with STEM. Participants completed their sacred STEM reflections on a biweekly basis. Through this activity, they were asked to become researchers and observers of the development math and cultural skills, but also to engage in critical dialogue and inquiry about what being women in STEM fields mean, personal reflections about STEM, and how the experience of an information learning activity can serve as a way to motivate and help those in need to seek STEM related fields. They were asked to record, write, and upload their biweekly sacred STEM reflections on an online course platform. Work within the tradition of ethnomathematics has shown that very sophisticated mathematical practices exist in essentially all cultures (Bishop, 1988).

Grounded in interpretive hermeneutics and phenomenology, it is a hybrid form of qualitative research that involves the gathering of reflections -focusing on the meanings that people ascribe to their experiences, seeking to provide "insight that [befits] the complexity of human lives" (Josselson, 2006, p. 4). This ongoing reflective practice serves as a way for BTCs to purposely focus on the effects of the pedagogical tool (the Nepo), their pedagogical practice, and content based (in this case math) practices, and their lived experiences.

\section{Findings}

The after-school Nepo project provided a tool for practical application of math and cultural skills for BTCs to engage in meaningful and purposeful pedagogy which they will someday use in their own classrooms (Machado-Casas \& Alanís, 2015). BTCs perceived the Nepo as a significant activity that provided them with important tools for learning and teaching because it facilitated a social construction of knowledge and afforded customized learning experiences (MachadoCasas, Alanís \& Ruiz, 2017).

BTCs used the Nepo as they reflected on their own math and cultural bilingual STEM considerations. BTCs were asked to view each other's experiences and explore similarities in the development of their collective identity as teachers, and finally they were asked to explain how the use of the Nepo to explore social issues and identity had enabled them to express and connect with their practice in an innovative way. Finally, they were also asked to reflect on how STEM was introduced to them prior to starting their teacher credential program. 
Findings reveal the significance of the activity for helping BTCs to understand how activities such as the Nepo can be used as a pedagogical tool in teacher education programs to transform the way we teach future bilingual teachers (Machado-Casas, Alanís, \& Ruiz, 2017). We focus on how exposing them to the informal learning activity led to a multisituational dialogue, opportunities to teach, connect, and transform learning for BTCs.

\section{Pipeline of gender and subject bias messages in teacher education: STEM is not for women}

One of the highlighted findings from this study was the idea that just as there is now a move to "pipeline" (to increase the number of teachers in areas of high need), there is also the reality that has resulted in the traditionally low numbers of bilingual STEM female teachers -the discouragement of women in bilingual STEM professions. This pipelining begins early on in elementary school and is fueled by a socio-historical and gender biased reality that discourages girls (women) from entering STEM fields (Machado-Casas \& Alanís, 2015). This treatment leads to a pipeline against promoting the capacity of bilingual women to enter STEM related fields. One participant had this to say:

As a child I was made to believe that I was bad at math. I liked it but my teacher did not encourage me to pursue it. This continued until the university level.

Another participant shared:

I remember when I used to tell my teachers that I wanted to do something on math and science -most would tell me "that's nice", but then proceed with other comments such as "leave that for the boys," or "not sure you need to do that becoming an English teacher or a bilingual teacher is easier". Always making me feel that I had to take the "easy" route, when in reality bilingual education is anything but easy. But also, just discouraging me from doing anything STEM related. I still think about this after all these years -it has not gotten away.

The quotes from the above participants reveals their own self-doubt about their mathematical abilities, she says "I was made to believe I was bad at math". Koch, Polnick and Irby (2014, p. vii) describe the struggle to find representation of girls and women in STEM as "a never-ending story". They provide a historical account for the lack of opportunities offered to women to enter STEM fields as a national problem that dates back as far as the 1970s. In the first example the participant situates math as a problem. She describes herself as being "bad" at math because she was made to believe she did not have the appropriate skills to excel in this content area. As a child, this participant felt like she "liked it but my teacher did not encourage me to pursue it". The first participant revealed that the ideologies imposed about math from an elementary teacher affected her own overall perceptions of what she could achieve in this area. The second participant noted that she was told that it was nice to like math and science, but "leave that for the boys" and pursue a career as an English teacher or bilingual educator because it was "easier". This example places an emphasis on the role of educators to nurture and foster students' desire to engage in specific academic areas, in this case, math. As a result of the child feeling that her teacher was not interested, she in turn decided to no longer excel in math. Not only did this affect her as a child in the beginning stages of her education, but the effects continued to impose problems throughout her educational trajectory and even in college. This example from one BTC provides insight as to how 
the pervasive problem with girls feeling the lack of competence in STEM fields is a result of societal conditioning: When math class at the university the professor said, "You girls don't worry about it, we will explain everything slower for you girls".

The roles of parents and teachers and their contribution to the stereotype threat of girls in STEM has also been accounted for (Inzlicht \& Ben-Zeev, 2000; Sekaquapetewa \& Thompson, 2003). Similarly, the second participant reveals that a university professor labeled her and the other female students in her math class as "slow" and not up to par with their male peers. In this instance the professor enacted a male driven savior mentality in which he would in essence rescue the girls by presenting the content information at a slower pace to accommodate their lack of skills. In essence, the university professor was perpetuating the stigma ascribed to girls in math, oftentimes women have to fight and confront these societal positionings of themselves.

However, this in and of itself can be problematic when these same women and girls have been subjected to discrimination in schools in STEM areas. Therefore, what ensues is an internal struggle they must confront to emancipate and liberate themselves. The repercussions of negatively relating girls' abilities in math and science have lasting effects on their selfesteem. Girls are left in a vulnerable position. Because they are told they lack the skills necessary to succeed in these areas, they are less willing to participate and take risks when engaging in math and science activities.

I grew up in an era where girls were not expected to do anything but marry. I wanted to study science and I was not allowed because I was a girl. Today as a woman of advanced age, I want to connect with my mathematical side. I came back to school to become a teacher but realized that not much has changed. The reality is that people talk about promoting STEM for girls and women, but it is not fomented at the university level. Not once before this time did I hear, "Hey, let's learn about STEM". On the contrary, instead I have heard, "Don't worry about it, that is not for you".

When considering opportunities afforded to children of color, numbers are scant. Hill, Corbett and St. Rose (2010) describe this lack of presence of girls of color in STEM as a disinterest because the tendency of STEM is to be based on the experiences of white women. Even as a child, this participant recalls not being afforded the opportunities to learn about STEM related fields in her $\mathrm{K}-12$ experience. Her revelation that upon entering a preservice teacher preparation program there were still no opportunities to learn or work in STEM related areas is a pervasive problem facing educator preparation programs. Several scholars attest to the need and challenging goals that face schools in engaging students of color in more meaningful and supportive ways in STEM education (McGee and Bentley, 2017; Brotman and Moore, 2008; Blickenstaff, 2006). Furthermore, this example illustrates how educators both in $\mathrm{K}-12$ schools as well as colleges continue to perpetuate the myth that girls are not good at math and science.

When I began looking for teacher education programs I went to several fairs. I noticed how men were immediately offered math positions. Even when they were not looking for them. I, on the other hand, would be offered to apply for a STEM position only after I highlighted my interest in doing it and the fact that I had worked as a tutor and aid in schools. Even without any previous experiences, these programs pre-screened me to teach English or social studies... Fields I really don't like at all. 
Given our current socio-political context, there are several stereotypes that pose threats to girls' and womens' perceptions of themselves when entering STEM fields. Shapiro \& Williams (2012) identify and attribute these threats to the underrepresentation of girls and women in STEM to the ways their performance and interest can be undermined by others. One of these threats has been identified as a "stereotype threat" (Shapiro \& Neuberg, 2007, p. 107). A "stereotype threat" can affect girls' and women in STEM in various ways including their performance on task and their career aspirations (Shapiro, 2011). This participant reveals that in her case, she came to the realization that men were perceived as more capable than women to teach math. She reveals the reality that women have to work harder and apply to teach in STEM related areas while men are given the positions even when "they were not looking for them".

Often times the situational nature of stereotype threats in STEM related activities are identified as environmental factors and ideologies held that exclude women and girls from STEM fields (Gunderson et al., 2011). This participant's account provides an example of how women are funneled and tracked into teaching areas such as English and social studies.
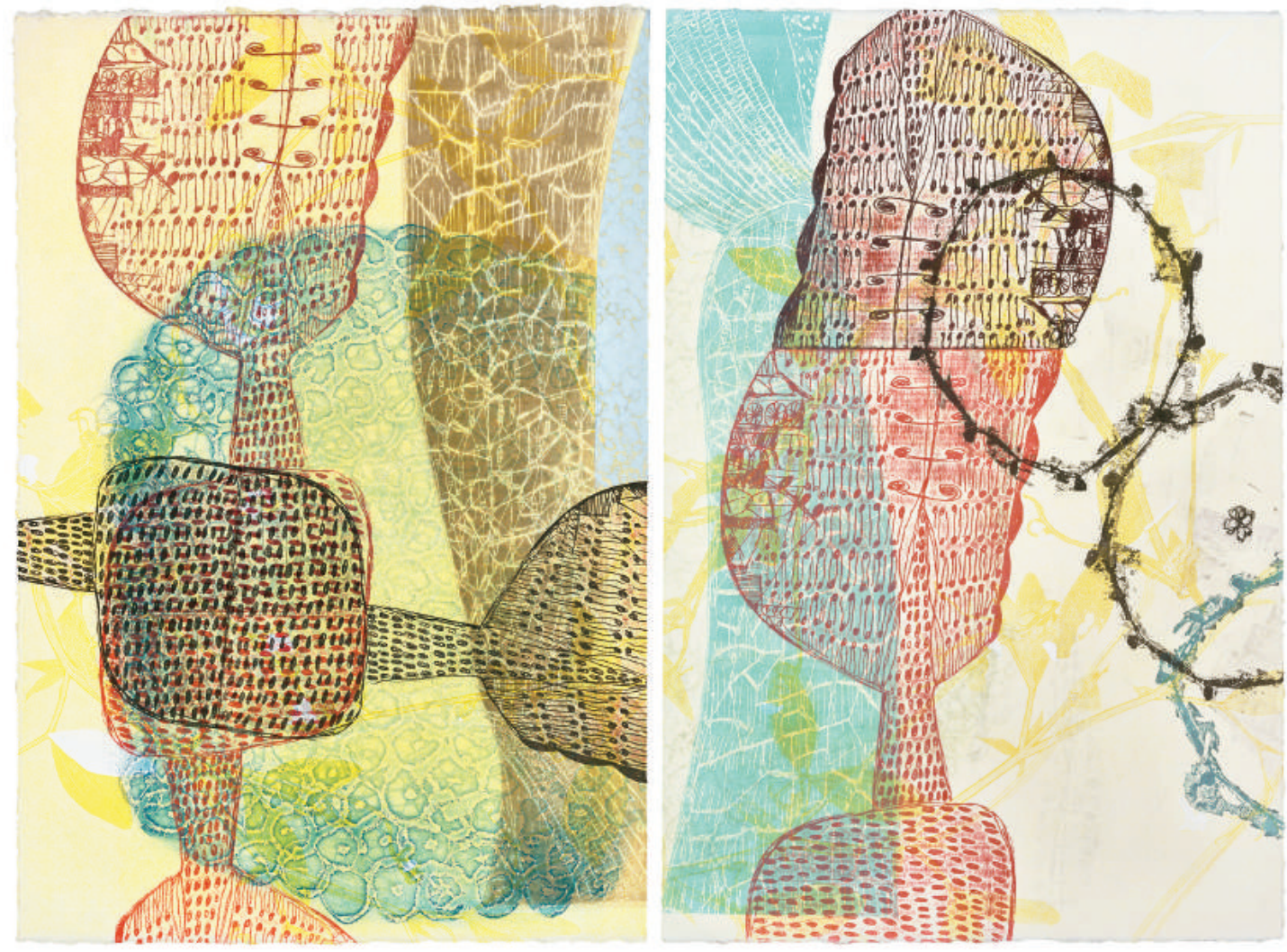

Eva Isaksen

"Together"

Xilografía, grabado

$57 \times 76.2$

2017

Seattle 
STEM related women empowerment: Addressing the lack of STEM related programing for women in teacher education programs

The teacher education field continues to be predominantly represented by women. Of these, a very small number focus on teachers of color. The work of Kohli reveals that, "teacher education programs often lack strategies and curriculum that speak to the needs of Teachers of Color" (Kohli, 2008, p. 187). Further research by Flores (2011) explains that Latina preservice teachers become "racialized tokens" who must learn how to navigate their way through a traditionally white woman's profession. Hernandez-Sheets argues that "teachers of color must be provided opportunities to transfer their prior knowledge of culture to pedagogical content knowledge" (Hernandez-Sheets, 2005, p. 166). This is what one of the BTC has to say about this:

I cannot think of any time I had a Latina woman as a STEM teacher. It was always a male dominated field. That always made me feel like I did not belong.

Another participant stated:

Although the field of teacher education is dominated by "women", it is really a space for men when it comes to STEM. It is exclusive.

To date, the majority of research on STEM education surrounds areas related to standards, principals, and practice while failing to account for the experiences of preservice women teachers of color. The work of Windschitl (2002) illuminates that the majority of teacher preparation programs train their teacher candidates to enter into the field ready to fully engage their students in science learning. Research and discussion regarding the need for improved quality in
STEM related fields in teacher preparation programs initially began in 1996. The National Commission on Teaching and America's Future stated that, "recruiting, preparing and retaining good teachers is the central strategy for improving our schools" (1996, p. 1). Luehmann (2007) argues that teacher preparation programs must provide their students with the knowledge and skills necessary to develop their own identities as science educators. Darling-Hammond (2006a) and Darling-Hammond \& Bransford (2005) present that powerful teacher preparation education programs equip their candidates with the skills and field experiences necessary to enter their future classrooms and serve their future students in high needs areas. Capraro, Capraro and Lewis challenge us "to consider the issues of STEM equity not in the common terms such as gender, ethnicity, or race but also in terms of identity, technology, opportunity, commitment, and challenge" (2013, p. 2). The work on preservice teacher preparation by Grossman (2010) identifies the importance of designing clinical teaching experiences where teacher candidates learn through multiple opportunities to practice, thus connecting the pedagogical knowledge they learn in their classrooms to their practicum experiences with students and cooperating teachers in the field.

I used to think that I was bad at math until I took this training. I really feel that the way I looked at math with fear stems from not having opportunities to explore these activities with other women -doing this activity with other women who felt the same way has been refreshing and invigorating -we are not alone. We can do this!

As noted above, there is great value in exposing BTCs to culturally relevant STEM activities such as the Nepohualzitzin. The work of Bravo, Mosqueda, Solis and Stoddart reveals that "preservice teachers strengthen 
their beliefs about diversity pedagogy in science when these practices are explicitly labeled, modeled and they receive feedback on their enactment of these practices" (2014, p. 617). Similarly, Ballanyte, Sanderman and Levy (2008) connect the experiences of preservice teachers in science courses to their ability to connect with and serve English language learner students. Tolbert, Stoddart, Lyon and Solis argue that "the challenge for teacher educators is to prepare teachers to teach ELs by integrating rigorous science instruction with the development of English language and literacy" (2014, p. 69). They add that in preparing preservice teachers, it is critical for programs to teach candidates how to promote the understanding of language skills in STEM fields. Providing BTCs these opportunities is critical in making sure that we are helping counter the gender, cultural, and professional bias that they are exposed to. When they enter teacher credential programs, universities need to do a better job at countering past experiences and exposing BTCs with opportunities that encourage them to enter the field.

\section{Conclusion}

\section{Hold up, you belong: Debunking the impostor syndrome as a form of resistance}

The "impostor syndrome" or feelings of self-doubt, especially for anyone who has just stepped into a new role (Clance, Dingman, Reviere \& Stober, 1995) was taking an effect on me. The impostor phenomenon has been studied since at least the 1970s when Pauline Clance and Suzanne Imes, two female clinical psychologists from Georgia State University, coined the term to describe "successful women who, despite reaching significant intellectual milestones ranging from advanced degrees to professional awards, cannot internalize their success or convince themselves they deserve it" (Kaplan \& Leckie, 2009, p. 468). Since then other researchers (e.g., Brems, Baldwin, Davis \& Namyniuk, 1994; Jarrett, 2010) have acknowledged such fears in adolescents and adults of all ages. Participants in this study noted that they felt like impostors, as if they did not belong. They also noted that this feeling was perpetuated from the time they were young and only grew as they moved from one level of educational schooling to another.

Teacher credential programs need to make a purposeful attempt to expose BTCs to culturally relevant STEM related activities that would allow BTCs interested in STEM related fields to pursue those fields. Given the trauma they have encountered, it is important that teacher education programs do as much as possible to counter these and reverse the feeling of being an "impostor". In purposely doing so, BTCs can have a tool to combat when the impostor syndrome creeps in, so they can remember that they belong there, and that they are not a phony or an impostor, but rather a consequence of socio-historical pipelining against women of color interested in STEM related fields.

\section{References}

Alanís, I., Machado-Casas, M., \& Ruiz, E. (2014). Beyond the technical aparatus: Identity, connections, and the use of "Autonarrativas virtuales" Virtual Autonarratives. NABE Journal for Research and Practice, 5.

Anyon, J. (1997; 2005). Radical possibilities: Public policy, urban education, and a new social movement. New York, NY: Routledge.

Avidad, M. M. (2014). La Clase Mágica: Creating Opportunities for Transformative Learning. In B. B. Flores, O. A. Vásquez, \& E. R Clark. (2014). Generating Transworld Pedagogy: Reimagining La Clase Mágica. Lanham: Lexington Publishers, Rowman Littlefield Publishing Group. 
Ballantyne, K. G., Sanderman, A. R., \& Levy, J. (2008). Educating English language learners: Building teacher capacity roundtable report. National Clearinghouse for English Language Acquisition \& Language Instruction Educational Programs. Washington, DC: George Washington University, Graduate School of Education and Human Development.

Bishop, A. J. (1988). Mathematical enculturation: A cultural perspective on mathematics education. Dordrecht, The Netherlands: Kluwer.

Blickenstaff, J. C. (2006,). Teacher leaders as intern supervisors: Lessons from an MSP Project. Bulletin of the American Astronomical Society. 38, 895-895. Bravo, M. A., Mosqueda, E., Solis, J. L., Stoddart (2014). Possibilities and limits of integrating science and diversity education in preservice elementary teacher preparation, Journal of Science Teacher Education, 25(5), 601-619.

Brems C., Baldwin, M., R., Davis, L., \& Namyniuk, L. (1994). The imposter syndrome as related to teaching evaluations and advising relationships of university faculty members. The Journal of Higher Education, 65(2), 183-193.

Brotman, J. S., \& Moore, F. M. (2008). Girls and science: A review of four themes in the science education literature. Journal of Research in Science Teaching: The Official Journal of the National Association for Research in Science Teaching, 45(9), 971-1002.

Capraro, M. M., Capraro, R. M., \& Lewis, C. W. (2013). Improving urban schools: Equity and access in K-12 STEM education for all students. Charlotte, NC: Information Age Publishing Inc.

Clance, P. R., Dingman, D., Reviere, S. L., \& Stober, D. R. (1995). Impostor phenomenon in an interpersonal/ social context: Origins and treatment. Women \& Therapy, 16, 79-96.

Darling-Hammond, L. (2006a). Powerful teacher education: Lessons from exemplary programs. San Francisco, CA: Jossey-Bass.

Darling-Hammond, L. (2006b). Constructing 21stcentury teacher education. Journal of Teacher Education, 57(3), 300-314.

Darling-Hammond, L., \&. Bransford, J. (2005). Preparing teachers for a changing world: What teachers should know and be able to do. San Francisco: Jossey-Bass.

Engeström, Y. (2001). Expansive learning at work: Toward an activity theoretical reconceptualization. Journal of education and work, 14(1), 133-156.

Flores, B., Cousin, P., \& Diaz, E. (1991) Transforming Deficit Myths About Learning, Language, and Culture. Language Arts, 5(68), 369-379.

Fry, R., \& Lopez, M. H. (2012). Hispanic student enrollments reach new highs in 2011: Now the largest minority group on four-year college campuses. Washington, DC: Pew Research Hispanic Center.

Flores, G. (2011). Racialized tokens: Latina teachers negotiating, surviving and thriving in a white woman's profession. Qualitative Sociology, 34(2), 313-335.

Flores, B. B., Vásquez, O. A., \& Clark, E. R. (2014). Generating Transworld Pedagogy:Reimagining La Clase Mágica. Lanham, MD: Lexington Publishers, Rowman Littlefield Publishing Group.

Gandara, P., \& Contreras, F. (2009). The Latino education crisis. The consequences of failed social policies. Cambridge, MA: Harvard University Press. 
Grant, C. A., \& Agosto, V. (2008). Teacher Capacity and social justice in teacher education. In $M$. Chchran-Smith, S. Feiman-Nemser, D.J. McIntyre, \& K. El Demers (Eds.), Handbook of research in teacher education (pp. 307-330). New York, NY: Routledge/Taylor \& Francis Group.

Grossman, P. (2010). Learning to practice: The design of clinical experience in teacher education. Washington, D C: Partnership for Teacher Quality.

Gunderson, E. A., Ramirez, G., Levine, S. C., \& Beilock, S. L. (2011). The role of parents and teachers in the development of gender-related math attitudes. Sex Roles, 66(3-4), 153-166.

Hanover Research Institute (2013). Student Perception Surveys and Teacher Assessments Prepared for XYZ. Recuperado de https://dese. mo.gov/sites/default/files/Hanover-ResearchStudent-Surveys.pdf

Hernandez-Sheets, R. (2005). Diversity pedagogy: Examining the role of culture in the teaching-learning process. Boston, MA: Pearson Education.

Hill, C., Corbett, C., \& St Rose, A. (2010). Why so few? Women in science, technology, engineering, and mathematics. Washington, DC: American Association of University Women.

Inzlicht, M., \& Ben-Zeev, T. (2000). A threatening intellectual environment: Why females are susceptible to experiencing problem-solving deficits in the presence of males. Psychological Science, 11, 365-371.

Jarrett, C. (2010). Feeling like a fraud: Christian Jarrett examines the psychology of the impostor phenomenon. The Psychologist, 23(5), 380-383.
Josselson, R. (2006). Narrative research and the challenge of accumulating knowledge. Narrative inquiry, 16(1), 3-10.

Kaplan, S., \& Leckie, A. (2009). The impact of English-only legislation on teacher professional development: Shifting perspectives in Arizona. Theory into Practice, 48(4), 297-303.

Knobel, M., \& Lankshear, C. (1999). Ways of knowing: Researching literacy. Newtown, NSW: Primary English Teaching Association.

Koch, J., Polnick, B., \& Irby, B. (2004). Girls and women in STEM: A never ending story. Charlotte, NC: IAP.

Kohli, R. (2008). Breaking the cycle of racism in the classroom: Critical race reflections from future teachers of color. Teacher Education Quarterly, 35(4), 177-188.

Ladson-Billings, G. J. (2005). Is the team all right? Diversity and teacher education. Journal of teacher education, 56(3), 229-234.

Lave J., \& Wenger E. (1991), Situated Learning: Legitimate Peripheral Participation. Cambridge: Cambridge University Press.

Lecusay, R. (2015). Building zones of proximal development with computer games in a UC Links after-school program. IJREE-International Journal for Research on Extended Education, 2(2), 13-26.

Luehmann, A. (2007). Identity development as a lens to science teacher preparation. Science Education, 91(5), 822-839.

Machado-Casas, M., \& Alanís, I. (2015). La tecnología como inclusión educativa de la diversidad cultural: Transformando prácticas informales de educación en 
los estados unidos. Diversidad Cultural e inclusión socioeducativa Journal, 5(1), 45-60.

Machado-Casas, M., Alanís, I., \& Ruiz, E. (2017/ Translated). Innovative Technologies as Social Pedagogy: Transforming Informal Educational Practices in the United States. Pedagogía Social. Revista Interuniversitaria, 29(3), 1-12.

Marsland,N., Wilson, l., Abeyasekera, S., \& Kleth,U. (1999) A Methodological Frame-work for Combining Quantitative and Qualitative Survey Methods. Reading, UK: Social and Economic Development Department, Natural Resource Institute and the Statistical Service Centre, University of Reading McGee, E. O., \& Bentley, L. (2017). The troubled success of Black women in STEM. Cognition and Instruction, 35(4), 265-289.

Mercado, C. I. (2012). Recruiting and preparing teachers for New York Puerto Rican Communities. A historical, public policy perspective. CENTRO. Journal of the Center for Puerto Rican Studies, 24(2), 110-139.

Miron, L. F. (1996). The social construction of urban schooling: Situating the crisis. Cresskill, NJ: Hampton.

National Commission on Teaching \& America's Future (US). (1996). What matters most: teaching for America's future: report of the National Commission on Teaching \& America's Future. New York: National Commission on Teaching \& America's Future.

Orfield, G. (2004). Dropouts in America: Confronting the graduation rate crisis. Harvard Education Press.8 Story Street First Floor, Cambridge, MA.

Orfield, G., Losen, D., Wald, J., Swanson, C. (2004). Losing our future: How minority youth are being left behind by the graduation rate crisis. Cambridge, MA: The Civil Rights Project at Harvard University.
Prieto, L., Claeys, L., \& Lara González, E. (2015). Transnational Alliances: La Clase MágicaNepohualtzitzin Ethnomathematics Club. Journal of Latinos and Education, 2(14), 125-134.

Rodríguez, L. F. (2014). The time is now: Understanding and responding to the Black and Latina/o dropout crisis in the U.S. New York, NY: Peter Lang Publishers.

Rumberger, R. W. (2004). Why students drop out of school. In Orfield, G. (Ed.), Dropouts in America: Confronting the graduation rate crisis (pp. 131-155). Cambridge, MA: Harvard Education Press.

Schuetze, A., Claeys, L., Flores, B. B., Schech, S. (2014). LCM as a Community Based Expansive Learning Approach to STEM Education. International Journal for Research on Extended Education, 2(2), 1-19.

Sekaquaptewa, D., \& Thompson, M. (2003). Solo status, stereotype threat, and performance expectancies: Their effects on women's performance. Journal of Experimental Social Psychology, 39, 68-74.

Shapiro, J. R. (2011). Different groups, different threats: A multi-threat approach to the experience of stereotype threats. Personality and Social Psychology Bulletin, 37, 464-480.

Shapiro, J. R., \& Neuberg, S. L. (2007). From stereotype threat to stereotype threats: Implications of a MultiThreat Framework for causes, moderators, mediators, consequences, and interventions. Personality and Social Psychology Review, 11, 107-130.

Shapiro, J. R., \& Williams, A. M. (2012). The role of stereotype threats in undermining girls' and women's performance and interest in STEM fields. Sex Roles, 66(3-4), 175-183. 
Sheets, R. (2004). Preparation and development of teachers of color. International Journal of Qualitative Studies in Education, 17(2), 163-166.

Swanson, C. (2004). Who graduates? Who doesn't? A statistical portrait of public high school graduation, class of 2001. Washington, DC: The Urban Institute.

Tolbert, S., Stoddart, T., Lyon, E. G., \& Solís, J. (2014). The next generation science standards, common core state standards, and English learners: Using the SSTELLA framework to prepare secondary science teachers. Issues in Teacher Education, 23(1), 65-90.

Valenzuela, A. (1999). Subtractive schooling: U.W.Mexican youth and the politics of caring. Albany, NY: State University of New York Press.
Vásquez, O. A. (2003). La Clase Mágica: Imagining optimal possibilities in a bilingual community of learners. Mahwah, N.J.: Lawrence Erlbaum Associates, Publishers.

Vygotsky, L.S. (1978). Mind in Society. Cambridge, MA: Harvard University Press.

Windschitl, M. (2002). Framing constructivism in practice as the negotiation of dilemmas: An analysis of the conceptual, pedagogical, cultural, and political challenges facing teachers. Review of educational research, 72(2), 131-175.

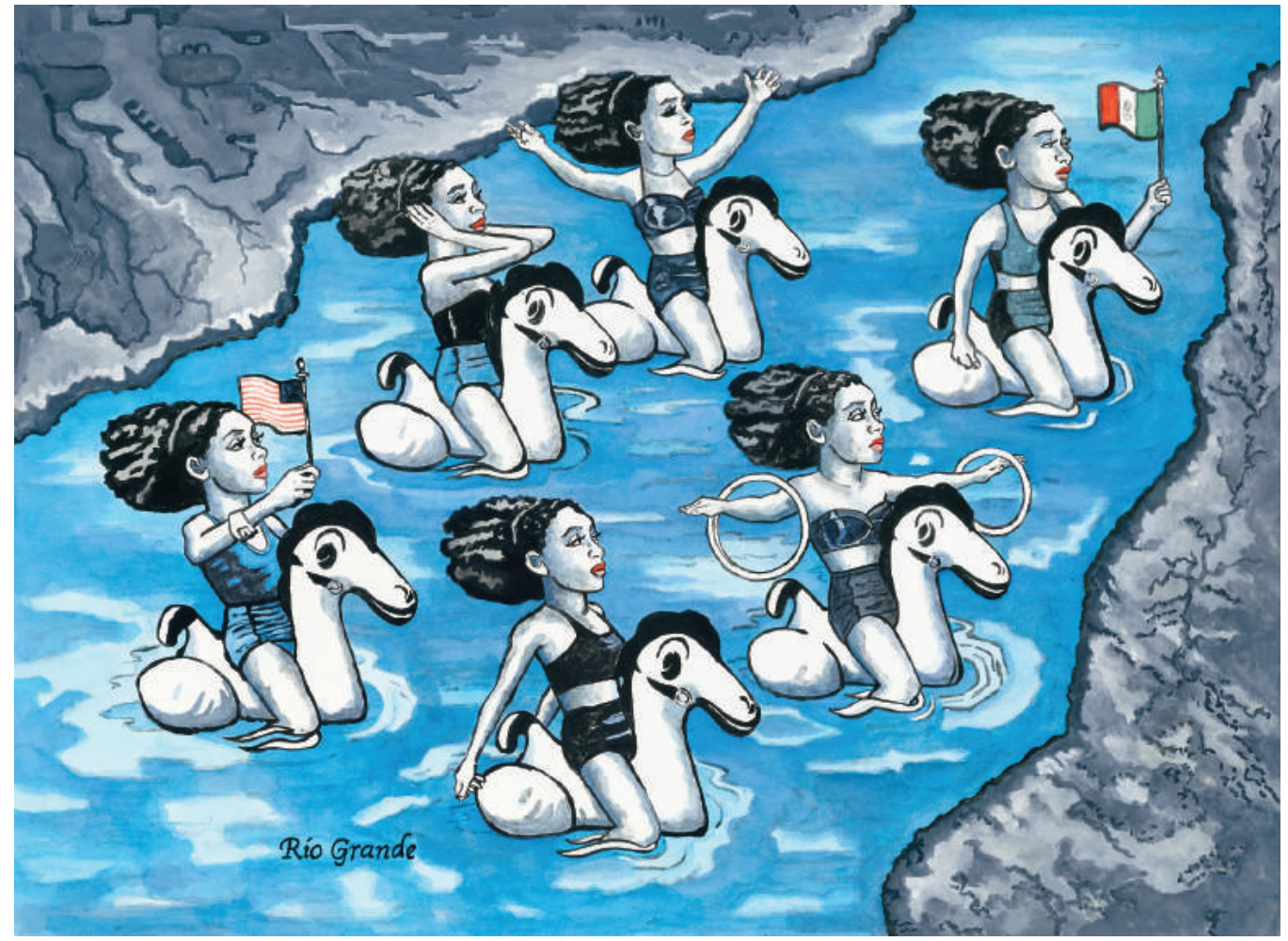

Gene Gentry McMahon "A Peaceful Crossing" Acuarela, monograbado $56.3 \times 76.3 \mathrm{~cm}$ 2018 Seattle 


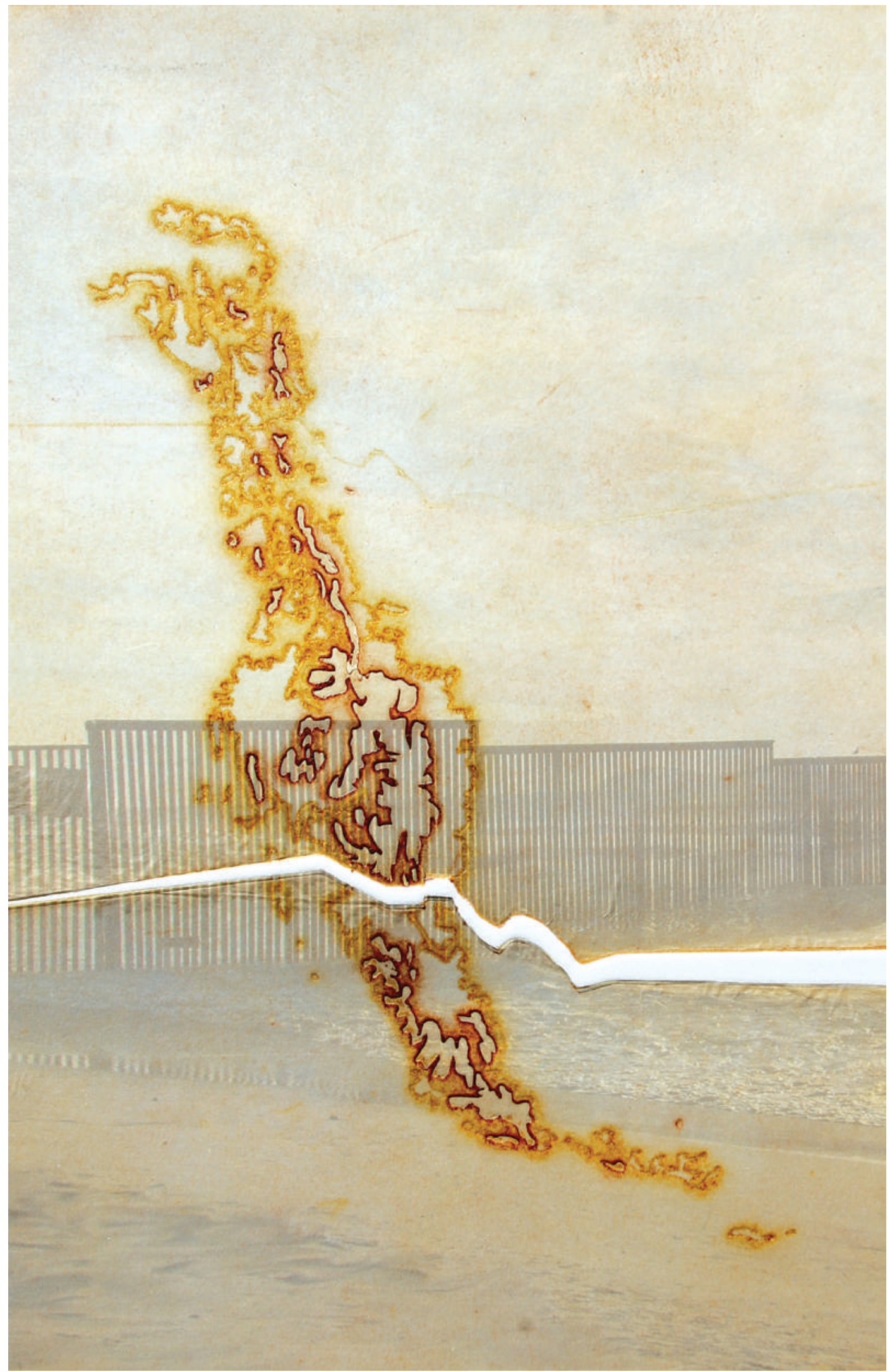

Anna McKee

"Broken Cordillera"

Colografía, ink jet y chine collé

$58.4 \times 45.8 \mathrm{~cm}$

2019

Seattle

Tequio, mayo-agosto 2020, vol. 3, no. 9 


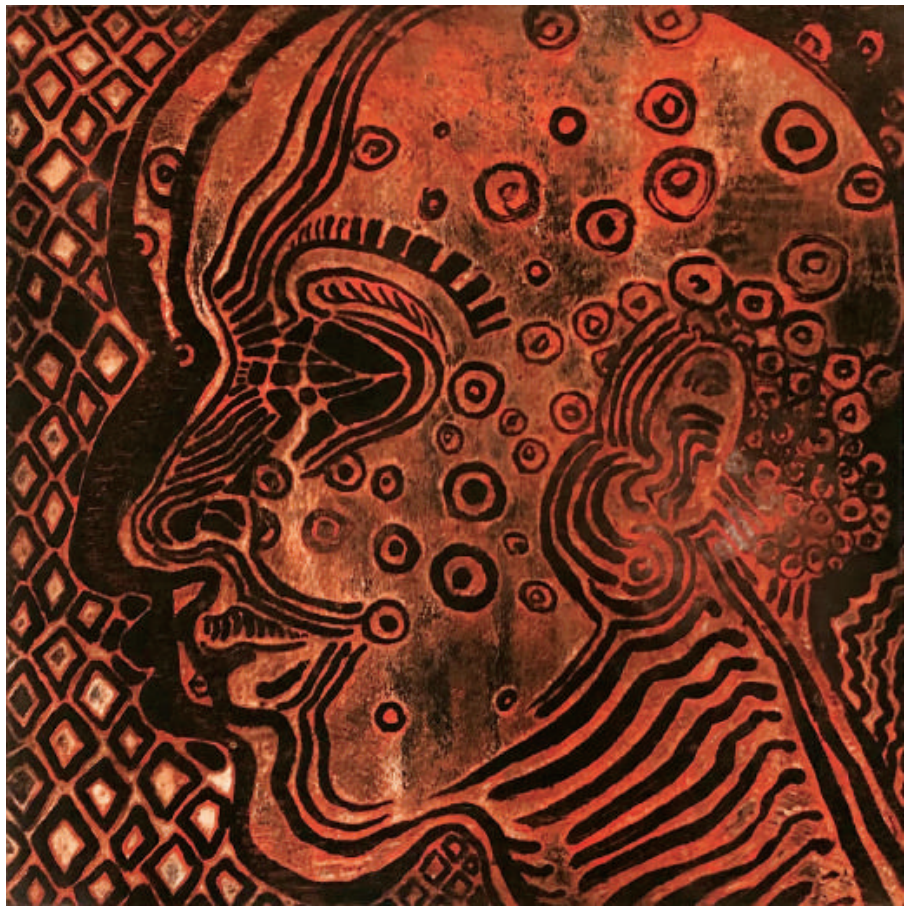

Enrique Gijón

"Tercera raíz"

Grabado sobre zinc

$42.5 \times 38.7 \mathrm{~cm}$

2019

Oaxaca

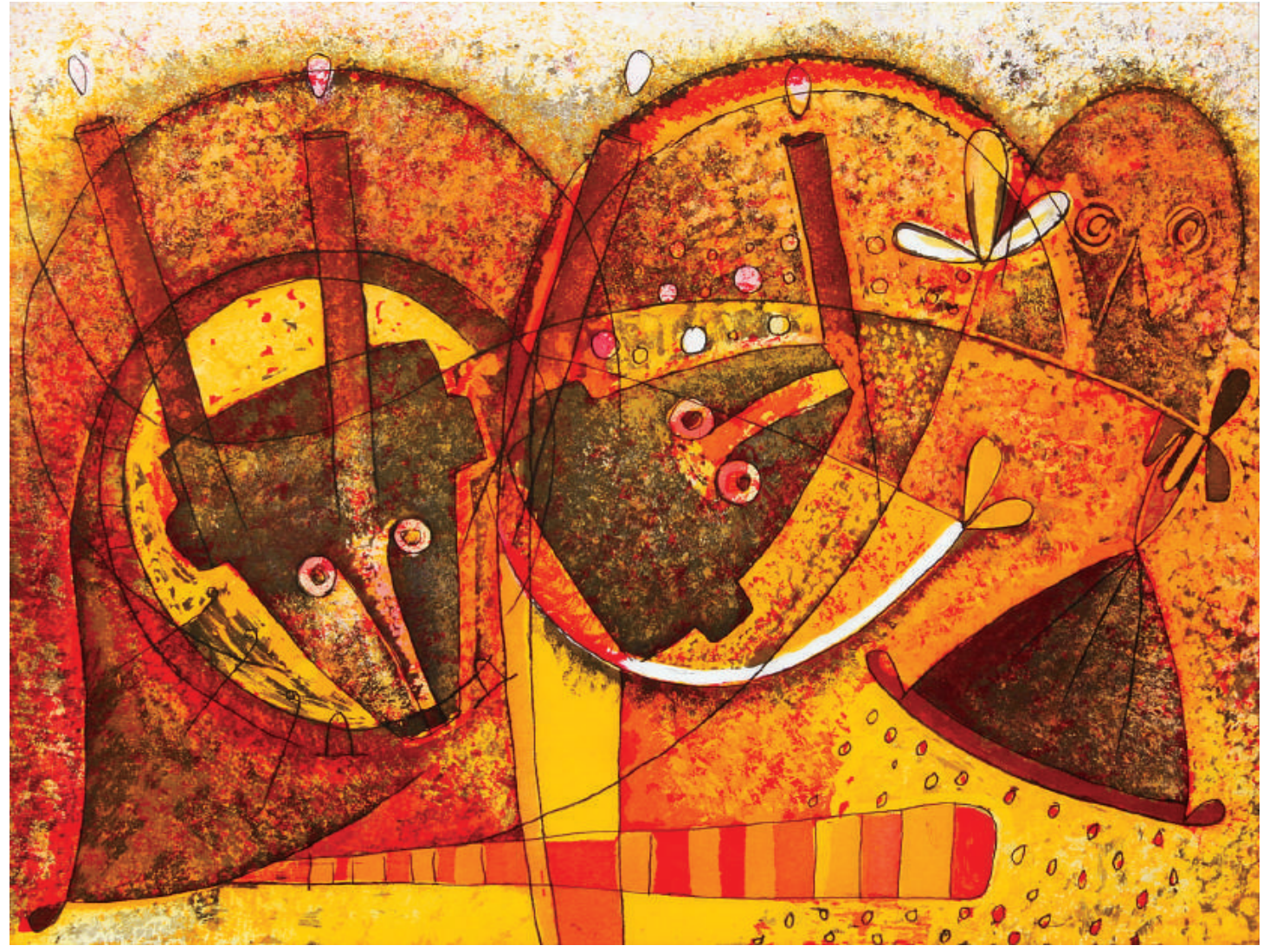

Fulgencio Lazo

"Viviendo en común"

Grabado en metal

$57.2 \times 71.7 \mathrm{~cm}$

2017

Oaxaca 